\title{
LOVE IT OR LEAVE IT: PROPERTY RULES, LIABILITY RULES, AND EXCLUSIVITY OF REMEDIES IN PARTNERSHIP AND MARRIAGE
}

\author{
SAUL LEVMORE*
}

I

\section{INTRODUCTION}

The traditional rule in partnership law is that a claim for "final accounting" is a partner's exclusive remedy. Under this rule, withdrawal from a partnership must precede or accompany legal actions against one's partners. A partner must "love it or leave it," with judicial attention available only after leaving the relationship. Rather plainly, this rule can be unfair and inefficient. At the same time, there is something attractive about the idea of encouraging private compromise by limiting the availability of courts to parties that are unable to continue their relationships.

Part II of this article introduces this tension by discussing the evolution of the rules of partnership law away from the love-it-or-leave-it, or "exclusivity," tradition and by comparing traditional partnership law first to domestic relations law, where the love-it-or-leave-it character of remedies is even more striking, and then to corporate law, where the structure of remedies is almost reversed. Parts III and IV connect this exploration of remedies to a familiar framework in the law-and-economics literature that compares property rules and liability rules. The connection reveals new ways of thinking about the remedies in partnership law and casts light on the occasional attractiveness of love-it-orleave-it rules. Part $\mathrm{V}$ compares the selection of remedies in business and in marriage, with some reference to other relationships as well. Part VI offers some concluding comments about love-it-or-leave-it strategies and the evolution of our legal system.

\section{II}

\section{LOVE-IT-OR-LEAVE-IT RULES IN PARTNERSHIP AND OTHER LAW}

Imagine that $A$ and $B$ are partners in a business and $B$ believes that $A$ has wrongfully exploited $B$ or otherwise breached the partnership agreement. The

\footnotetext{
Copyright $\odot 1995$ by Law and Contemporary Problems

* Brokaw Professor of Corporate Law and Albert Clark Tate, Jr., Professor, University of Virginia.

I am grateful for comments received from Chris Akin, Jim Bowers, Peggy Brinig, Glen Robinson, Bill Stuntz, and especially Larry Ribstein, as well as participants at a University of Virginia Law School faculty retreat.
} 
traditional rule is that if $B$ seeks damages from $A$ or from the $A B$ partnership for the alleged wrong, $B$ will be required first to ask the court for a final accounting, which in turn often requires the dissolution of the partnership. ${ }^{1}$ On its face, the rule denies $B$ the power to sue the ongoing partnership enterprise while simultaneously avoiding the costs of dissolution, the most important of which may be the value of B's share of the ongoing concern. ${ }^{2}$ It is easy to imagine that this exclusivity (of remedies) rule can leave wrongs uncorrected and in this way permit an unhealthy degree of exploitation of a minority partnership interest. A related intuition is that when the future prospects of a partnership look promising, one partner may be especially tempted to exploit another unless there is reason to fear external legal intervention. This intuition, however, is difficult to pin down.

There are at least three strategies for understanding the traditional exclusivity, or all-or-nothing, rule and the steady migration away from this seemingly strange, anachronistic, unfair, and inefficient rule. ${ }^{3}$ First, we might examine partnership cases in order to identify the inevitable exceptions to the rule. Most harsh or striking rules have numerous exceptions, and this one is no different. ${ }^{4}$ As the exceptions grow in number and importance, the original rule is more likely either to appear in retrospect to have reflected some evolutionary or legal accident or be otherwise anachronistic. Either way, surging exceptions can be taken as evidence of healthy evolution away from the rule. If we focus on either of two straightforward explanations of the origin of this particular exclusivity rule-with no attention to similar rules in other areas of law-evolution and abandonment of the rule seem predictable. One explanation suggests that the rule arises out of a formalist conception of the "aggregate theory" of partnerships. ${ }^{5}$ Courts in an earlier era might have had trouble imagining a lawsuit going on within a partnership, much as we would find it bizarre to imagine or to allow one division of a corporation to sue another

1. See, e.g., Goff v. Bergerman, 50 P.2d 59, 61 (Colo. 1935) (the exclusivity rule requires both a final accounting and a settlement of partnership affairs); see also 2 ALAN R. BROMBERG \& LARRY E. RIBSTEIN, BROMBERG AND RIBSTEIN ON PARTNERSHIP \$ 6.08(b) (1988) ("Prior to the [Uniform Partnership Act], the action for an accounting was generally denied except incident to dissolution.").

2. This assumes that the going concern value will not always be salvaged by a purchase and refinancing on the part of a surviving partner. If going concern value (partnership value) is never lost-which under some rarefied economic assumptions is the case-then most of the rules discussed in this paper make no difference at all. But there are reasons to think that withdrawals can sink profitable enterprises. For example, outsiders, including creditors, may have difficulty discerning which enterprises have going concern value. Moreover, there are arrangements where continuity can be threatened because of legal or other institutional hurdles. Thus, partners may bring unique skills or legal licenses to a venture-all of which may be inalienable-so that dissolution can be mutually threatening and not simply overcome by a buyout.

3. See infra notes 8-14 and accompanying text.

4. See infra note 8.

5. When treating partnerships as aggregates of individuals, "suing a partnership would be characterized [by the common law] as being on both sides of the case." BROMBERG \& RIBSTEIN, supra note 1 , at $\$ \S 1.03(\mathrm{~b}), 6.08(\mathrm{c})$. The exclusivity rule survived a gradual shift toward an "entity theory" of partnerships. Id. $\$ 6.08$ (c); see also Sertich v. Moorman, 783 P.2d 1199, 1201 (Ariz. 1989) (noting that earlier courts did not view the partnership as separate entity). 
division of the same firm. ${ }^{6}$ The second explanation for the origins of the exclusivity rule can be drawn from the distinction between law and equity. ${ }^{7}$

As for the evolution of the exclusivity rule in partnership law, there are in fact modern cases that virtually dispose of the rule. ${ }^{8}$ The Uniform Partnership Act encourages the demise of the rule, although there is some reason to think that the rule lives on despite what a casual reading of the Act would first suggest. ${ }^{9}$ The "Revised" Uniform Partnership Act seeks to bury the exclusivity rule by allowing almost any cause of action by a partner against the partnership or against other partners without a final accounting or dissolution. ${ }^{10}$ Further

6. John Collyer, Practical Treatise on the Law of Partnership $\$ 264$ (5th ed. 1861) ("useless for one partner to recover what, upon taking a general account amongst all partners, he might be liable to refund").

Another explanation for the exclusivity rule is that it saved judicial resources. See infra note 71.

7. The exclusivity rule on its face is about the distinction between law and equity. The rule precludes suits at law until after the equitable remedy of a full accounting has been had. Sertich, 783 P.2d at 1201-02 (describing the exclusivity rule as an anomaly that arose from the common law distinction between law and equity).

8. Id. at 1201-05 (abandoning the exclusivity rule in Arizona). For more limited exceptions, see Hanes v. Giambrone, 471 N.E.2d 801 (Ohio Ct. App. 1984) (action to collect partnership contributions with no accounting); Fulton v. Baxter, 596 P.2d 540 (Okla. 1979) (fiduciary breach suit in absence of accounting). More generally, courts have made an exception for situations in which "by some special agreement the particluar matter has been withdrawn from the partnership account." Kunneke v. Mapel, 53 N.E. 259, 261 (Ohio 1899). Similarly, courts have allowed the equitable remedy of a constructive trust without requiring accounting and dissolution. BROMBERG \& RIBSTEIN, supra note $1, \S 6.08$ (c)(8). See generally Susan Swinson, Partner v. Partner: Actions at Law for Wrongdoing in a Partnership, 9 GA. ST. U. L. REV. 905 (1993).

9. As noted below, any reference to the Uniform Partnership Act, or UPA, risks ambiguity because the "current" Uniform Partnership Act (1994) is commonly but not officially referred to as the Revised Uniform Partnership Act, or RUPA. The 1914 Act (with the usual changes over the years) is commonly referred to as the Uniform Partnership Act. In any event, the immediate reference in the text is to the better known Uniform Partnership Act (1914). In terms of the issues discussed here, its basic structure is as follows: (1) Any partner can force dissolution unless there is an agreement to the contrary, including an express or implied agreement to continue the partnership for a specified term. See UNIF. PARTNERSHIP ACT \& 31 (last amended 1914), 6 U.L.A. at 376 (1969). Moreover, any partner can terminate a partnership, although doing so may breach the agreement. Id. $\S \S 31,38,6$ U.L.A at 376,456 . Any partner has a right to formal accounting (without dissolving the partnership) when (a) wrongfully excluded from the business, (b) if the partnership agreement provides for the right, (c) a partner has appropriated an unauthorized benefit, or (d) whenever it is just and reasonable. $I d$. $\S 22$, 6 U.L.A. at 284.

The UPA (1914) thus encourages evolution away from the exclusivity rule by allowing courts to describe claims (that include claims for full accounting but do not call for dissolution) as "just and reasonable." Nonetheless, because the claimant must obtain an accounting (even without dissolution), there is still an element of an all-or-nothing choice because the cost of an accounting (and the added animosity arising from a legal action that imposes serious costs on the partnership) will discourage actions in profitable partnerships. BROMBERG \& RIBSTEIN, supra note $1, \S 6.08$ (b) (noting that predissolution accounting actions are rare for these reasons).

10. The Uniform Partnership Act (1994), previously and commonly known as the Revised Uniform Partnership Act, or RUPA, abandons the exclusivity rule by allowing a partner to sue the partnership or other partners for almost any cause of action without seeking an accounting. RUPA $\$$ 405(b) (last amended 1994), 6 U.L.A. 280, 316 (Supp. 1995). Dissolution or, in the language of this Act, "dissociation," remains something that can always be done, rightfully or wrongfully. Id. $\$ 602,6$ U.L.A. at 325. The Official Comment to the new (model) statute notes that the abolition of the exclusivity rule "reflects a new policy choice that partners should have access to the courts during the term of the partnership to resolve claims against the partnership and other partners, leaving broad judicial discretion to fashion appropriate remedies." RUPA $\$ 405$ (b), 6 U.L.A. at 316 n.2 (Supp. 1995). 
focus on this first approach is unnecessary; a healthy evolution away from a suboptimal and dated rule may be optimistic, lawyerly, and plausible, but it is perhaps limited in relationship to partnership law. Moreover, the most sophisticated commentators already follow this strategy. ${ }^{11}$

A second approach to understanding the exclusivity rule, and the evolution away from it, is to have some confidence in the lawmakers of earlier eras and explore the possibility that the evolution from one rule to another reflects the fact that reasonable observers might be uncertain which of several rules is superior. ${ }^{12}$ The exceptions that materialize in the shadow of a rule might provide hints as to the perceived disadvantages of that rule. ${ }^{13}$ The discussion below suggests that it is not obvious how to choose between conflicting strategies for motivating peaceful compromise while discouraging strategic exploitation among quarreling parties. The exclusivity rule in partnership law might be one strategy aimed at this end, but it is difficult to evaluate, and, therefore, it is an approach that might give way to permitting piecemeal litigation and anticipating legal intervention in ongoing partnerships. In turn, this latter approach might itself be displaced over time, when a return to exclusivity is possible.

Finally, a third, though not necessarily unrelated strategy is to generalize the problem and to ask when similar all-or-nothing rules are found in law. Much as the traditional partnership rule tells a potential complaining partner that he or she must love-it-or-leave-it, which is to say simply end the relationship or not litigate at all, there are other areas of law where litigants must elect between such extremes. The most familiar example is in domestic relations law. ${ }^{14}$

11. See Larry E. Ribstein, The Revised Uniform Partnership Act: Not Ready for Prime Time, 49 BUS. LAW. 45, 61 (1993).

12. See Saul Levmore, Variety and Uniformity in the Treatment of the Good-Faith Purchaser, $16 \mathrm{~J}$. LEGAL STUD. 43 (1987).

13. Thus, there is evidence that courts imply agreements as to limited terms where no such explicit agreements existed, in order to impose liability on a partner who ends a partnership with going concern value. See Robert W. Hillman, The Dissatisfied Participant in the Solvent Business Venture: $A$ Consideration of the Relative Permanence of Partmerships and Close Corporations, 67 MINN. L. REV. 1, 20-27 (1982)[hereinafter Hillman, The Dissatisfied Participant]. Professor Hillman, it should be noted, disapproves of this judicial practice. Id. Foreign jurisdictions, interestingly enough, do not allow partners to leave and pay damages if their partnership is for a specified term. See Robert W. Hillman, Indissoluble Partnerships, 37 U. FLA. L. REV. 691, 694-95 (1985). In unusual cases, U.S. courts may do the same, perhaps in order to force bargaining. See Infusaid Corp. v. Intermedics Infusaid, Inc., 739 F.2d 661 (1st Cir. 1984). The apparent choice for courts between damages and prohibitions is the subject of parts IV and $\mathrm{V}$ below.

The second approach described in the text differs from the "healthy evolution" described in the first approach, in that the second approach anticipates a resting point with multiple equilibria rather than a sense that less exclusivity is generally if not always better than more. Moreover, there is the possibility that courts develop schemes in which love-it-or-leave-it rules are used for some cases and not others, with the courts enjoying some flexibility when it comes to determining partnership liabilities. It may be that the constructive trust exception to the exclusivity rule, see supra note 8 , provides one useful judicial tool.

14. The most familiar examples to lawyers may be the love-it-or-leave-it rule regarding attorneyclient litigation and the treatment of joint tenants and cotenants in property law. As for the first of these, an attorney may not be on the opposite side of any litigation from his or her client. MODEL Rules of Professional CONDUCt Rule 1.7(a) (1983); see Lake County Bar Ass'n v. Gargiulo, 404 
Indeed, if this article were not part of a symposium organized around partnership law, it might have been most sensible to focus first on family law, and especially on the normal exclusivity of the divorce remedy as a means of asking why other areas of law evolved away from, or in some cases never adopted, the all-or-nothing judicial attitude that is found where complaints about marriage are concerned.

In the law of domestic relations, we do not expect a court to award contract damages to a plaintiff who complains about a spouse's misconduct or laziness or breach of an interspousal promise. Such a remedy might accompany or be a part of a divorce settlement, or might simply be unavailable because of the exclusive character of the divorce remedy. ${ }^{15}$ The judicial practice is not simply the result of adhering to a nonmarket conception of a woman's traditional work as wife and mother; a husband would also have trouble collecting damages from a wife who broke a promise concerning the maintenance of hearth and home (and had property with which to pay a judgment). ${ }^{16}$ And either spouse would

N.E.2d 1343 (Ohio 1980) (lawyer disciplined after filing in same action claims on his own behalf against
each client and by each client against the other). Thus, an attorney may not even sue a client for
unpaid fees-until the entire attorney-client relationship comes to an end. Disclosure does not free the
attorney of this constraint. There is, of course, sometimes the option of ending the relationship and
forcing (which may be to say threatening) the client to seek other counsel and pay twice for some work.
See 7 AM. JUR. 2D Attorneys at Law $\$ 306$ (1980). This love-it-or-leave-it rule does not, however, seem
to have much to do with other love-it-or-leave-it rules. It appears to reflect the special concern of the
law for conflicts or appearances of conflict between lawyer and client. The law worries that lawyers
may seem to root against their own clients if they are also seen to be in open conflict with these clients.
This concem may be misplaced, for it is arguable that uncollectible fees or unresolvable conflicts may
in fact lead to greater agency problems, but it is probably safe to set aside this love-it-or-leave-it rule
as a special case.

In the case of multiple ownership of property, there is a striking love-it-or-leave-it rule when courts will not intervene in disputes among joint tenants or cotenants until one asks for a partition. See JOHN E. CRIBbet \& CORWIN W. Johnson, PRINCIPLES OF THE LAW OF PROPERTY 113 (3d ed. 1989). The law in this area can also be explained as minimizing valuation tasks. See infra part V.B (valuation tasks may explain difference between marriage and business partnership); Saul Levmore, Explaining Restitution, 71 VA. L. REV. 65, 70 (1985) (valuation considerations may explain rule permitting joint tenant to recover for improvements to property only in partition). It goes almost without saying that a common feature of many joint tenancies, cotenancies, and business partnerships (and all marriages) is that the parties have familial ties. In these settings, courts may think either that it is especially likely that compromises will eventually be reached or that it will be difficult to unravel the numerous interactions and identify the initial or true wrongdoer.

15. Following, or along with, dissolution, courts may pass on claims for conduct during the marriage. Remedies may be reflected in the division of property at divorce or in separate judgments. See, e.g., Henriksen v. Cameron, 622 A.2d 1135 (Me. 1993) (allowing action following a no-fault divorce by former spouse for intentional infliction of emotional distress during marriage); Roland v. Roland, 519 So. 2d 1177 (La. Ct. App. 1987) (finding wife's intemperance constituted independent contributory cause of marital breakup thus precluding permanent alimony). But it appears that as state legislatures move toward no-fault divorce, legislatures and courts are less inclined to look back, or at least give less weight to, behavior within the marriage in dividing property. HOMER H. CLARK, JR., THE LAW OF DOMESTIC RELATIONS IN THE UNITED STATES $\$ 1.1$ (2d ed. 1988).

This explanation does not include tort claims between spouses because the evolution away from the spousal tort immunity is easily linked to the desire to mesh tort claims with typical insurance coverages. The movement toward allowing these claims within marriage thus does not seem like much of an exception to the larger love-it-or-leave-it rule.

16. Reva Siegel, The Modernization of Marital Status Law: Adjudicating Wives' Rights to Earnings, 1860-1930, 82 GEO. L.J. 2127 (1994). 
find it impossible to collect damages or gain specific performance from a spouse who for selfish reasons failed to maximize his or her earnings. ${ }^{17}$ Whether courts aim to encourage compromise with a love-it-or-leave-it rule or simply refuse to monetize or otherwise become entwined in ongoing spousal relations, there is little doubt that this is an area of law where the expected outcomes are limited to self-help, private negotiation, or the extreme step of dissolution.

In contrast, a shareholder of a corporation can pursue a claim against an agent, or fiduciary, while continuing to own stock in the corporation. ${ }^{18}$ Somewhat similarly, an employee can sue her employer (and, conversely, the employee can be sued) without severing the employment relationship. To be sure, it may be awkward to sue one's boss, but the point is that love-it-or-leaveit in these cases is a private, rather than a legally imposed, constraint on one's options. Other fiduciaries can also be sued while their services continue. ${ }^{19}$ There is, therefore, the general question of when love-it-or-leave-it rules are attractive. ${ }^{20}$

One indication that this question is unlikely to yield simple answers is that closely allied areas of law (which is to say similar transactions and relationships) sport sharply divergent rules. Thus, while marriages and business partnerships might seem similar-if only because partnerships are often formed among

More generally, an explanation of the love-it-or-leave-it rule in marriage might build on the idea that women were relatively disadvantaged by a rule that made divorce a prerequisite for other interspousal claims. The point in the text, however, is that the law might have disadvantaged women still more by allowing men (and not women) to bring suits in marriage when their expectations were disappointed. The law was not above such a facially nonneutral rule.

17. Indeed, it would be no simple task to collect explicitly promised amounts. See Miller v. Miller, 42 N.W. 641 (Iowa 1889) (refusing to enforce written agreement between husband and wife promising fidelity and $\$ 200$ per year for wife's personal use despite husband's breach by "wasting his money on other women").

18. In derivative actions in Delaware, for example, the plaintiff must remain a stockholder throughout the litigation. Lewis v. Anderson, 477 A.2d 1040 (Del. 1984); In re Resorts Int'l. Shareholders Litig., C.A. No. 9470, slip op. at 31 (Del. Ch. Sept. 7, 1988), aff'd, 570 A.2d 259 (Del. 1990). See generally ROBERT CHARLES CLARK, CORPORATE LAW 650-52 (1986) (contemporaneous ownership rule normally requires shareholder who brings derivative suit to allege that he was a shareholder at time of transaction of which he complains-and also to hold shares when bringing suit and throughout the suit).

19. The remedies available to the beneficiary of a trust, for example, generally include declaratory judgments interpreting the trust, UNIF. DECLARATORY JUDGMENTS ACTS $\$ 2$ (1922), injunctions against wrongful acts, GEORGE T. BOGERT, TRUSTS $\$ 154$ (1987), specific performance, id. § 155, and money damages, id. $\$ 157$. These actions need not result in the removal of the trustee. Id.

20. There is a normative and a positive angle to the question, but for the present there does not seem to be a reason to separate these inquiries. The present inquiry can also be thought of as asking the positive question of why, if in some areas of law love-it-or-leave-it rules are found attractive, such rules are not more commonly used. I have tried to ask similar questions about other rules we do not often find, with the hope that we can learn a good deal about the law that we do experience by exploring the laws we do not. See, e.g., Saul Levmore, Gomorrah to Ybarra and More: The Puzzle of Immoderate Group Liability, 81 VA. L. REV. 1561 (1995) (puzzle of failure of law to experiment with extreme form of group liability in order to extract confessions from rational wrongdoers); Saul Levmore, Obligation or Restitution for Best Efforts, 67 S. CAL. L. REV. 1411 (1994) (contractual acquaintances rarely recover for apparently wealth-maximizing precautions); Saul Levmore, The Case for Retroactive Taxation, 22 J. LEGAL STUD. 265 (1993) (exploring general hostility to retroactive taxes even though such taxes have certain attractive qualities). 
relatives-so that their once-analogous love-it-or-leave-it rules suggest consistency, it is not the case that employer-employee law, or principal-agent law more generally, has insisted on such exclusivity. For example, in the principal-agent context, if B contracts with $\mathrm{A}$ to sell A's products and to earn a commission on all sales, B and A may sue one another regarding explicit or implicit violations of their agreement, even while they continue to enjoy the going concern value of their relationship by respectively supplying and selling products as before. ${ }^{21}$ The exclusivity tradition in partnership law is therefore especially remarkable because partnerships are easily and most often described as mutual agency arrangements.

The occasional attraction of love-it-or-leave-it rules is particularly intriguing because in many cases rules about the exclusivity of remedies are not merely default rules but are instead virtually mandatory. It can be difficult, if not impossible, for parties to modify or otherwise escape love-it-or-leave-it rules through private bargaining. Thus, partnership law has generally permitted a partner to force a dissolution, but, as we have seen, the traditional rule did not permit most litigation outside the context of a final accounting. One way to contract out of the first half of this love-it-or-leave-it rule is to specify that the partnership is for a set period of time or for a distinct project. In that case, there is no right to a "free" dissolution but rather an explicit agreement to give up the right to withdraw for a set period of time. ${ }^{22}$ However, this strategy for private ordering does not solve the problem of the partner who seeks judicial intervention or enforcement of an agreement without separation. Thus, the love-it-or-leave-it rule may have forced a kind of bundling on some unwilling players. $^{23}$ Similarly, potential partners might wish to prevent untimely

21. E. ALLAN FARNSWORTH, CONTRACTS $\S 8.15$ (1982).

22. See supra note 9! UPA $\$ \S 31,38,6$ U.L.A. at 376,456 . The rule continues under RUPA $\$ 602$, 6 U.L.A. at 553 (dissociation is within power of partner but is wrongful if prior to expiration of definite term or completion of particular undertaking). The general rule is that every partner has the power to dissolve a partnership at any time, even though a partnership agreement may try to limit or deter that power. In particular, the exercise of this power before expiration of a specified term may make the partner liable for damages. McCall v. Frampton, 415 N.Y.S.2d 752 (1979); Woodruff v. Bryant, 558 S.W.2d 535 (Tex. Civ. App. 1977).

23. Similarly, spouses might wish to precommit never to get divorced, but the law does not provide for this option and makes bargaining around the default rules and in favor of this precommitment strategy very difficult. In the case of business partnerships, it is preferable to say that the law disfavors some packages, rather than that it makes them impossible, because it is difficult to know how courts would react to clever schemes. Thus, parties might use nested partnerships in order to dissolve one partnership while continuing to do business together in a successor partnership, but with the intention of using the "dissolution" as a means of getting into court with their claims. It is difficult to know whether courts, operating under the traditional rules, would be willing to allow such a strategy, and the most noteworthy thing may be that parties apparently have not tried this route around the love-it-orleave-it norm.

The mandatory nature of some of these rules does not make it impossible to describe the love-it-orleave-it rules discussed in this article as examples of precommitment strategies. Investors might occasionally wish to precommit to all-or-nothing rules (no litigation short of dissolution), and this is indeed what is meant by the possibility of traditional partnership and corporate law offering different default rules. Similarly, spouses may wish to precommit to be unable to litigate short of divorce, and it is even remotely possible that nations would want to precommit to ban conventional weapons. See 
dissolution (or threats of dissolution) and also to allow claims within the ongoing relationship, but under the traditional rule they find it difficult to do so. Analogously, spouses cannot successfully contract around their love-it-orleave-it relationship.

\section{III}

\section{EXCLUSIVITY RULES AND BARGAINING}

\section{A. Two Kinds of Exclusivity}

The domestic relations example suggests that an important aspect of love-itor-leave-it rules is the impetus they might give to private bargaining. It is at least plausible that the threat of withdrawal, be it from marriage or from a business partnership, facilitates settlement by jeopardizing the value of a going concern. The law might impose a love-it-or-leave-it framework on parties-who might themselves be thought of as precommitting to this set of choices or to this strategy-because of a conviction that they will choose to iron out their differences in the shadow of destructive dissolutions. The most obvious alternative regime is one that permits and perhaps even encourages midstream appeals to judicial authority. One implicit question is whether a love-it-or-leaveit rule generates more or less private bargaining or compromise than a scheme that permits ongoing appeals or judicial intervention. Another question is whether the choice between these schemes is likely to influence the outcome of private bargaining in an important way.

Consider the relative desirability of two opposing exclusivity schemes. The first, resembling the traditional partnership rule-and in some respects the law governing marriages-promises liquidity by offering every participant the right to exit with the net value of that participant's share in the enterprise, but allows no other remedy. The threatened coventurers may bargain, especially if the withdrawal of this participant makes it difficult for those who wish to continue on to do so, but they instead may think it unlikely that the threat will be carried out inasmuch as the threatening partner risks losing his share of the going concern value of the partnership. ${ }^{24}$ Put differently, the right to exit or dissolve invites a kind of "chicken" game that almost surely reduces litigation but occasionally invites the baby to be thrown out with the bath water. This love-itor-leave-it strategy may lead to accommodation rather than separation, although

infra part V.D.1. But some of these love-it-or-leave-it strategies seem like unlikely precommitment strategies. We are accustomed to love-it-or-leave-it precommitments where coalitions are malleable and voting paradoxes flower, as in Congress agreeing to vote up or down (love-it-or-leave-it) the proposals of a military base closing commission, but such precommitments would seem unusual or even counterintuitive where two parties were concerned. Put differently, it is the (at least somewhat) mandatory quality of these rules that makes them different and more interesting.

24. All partners may know that the value of the firm exceeds that which a suspicious outsider would pay. See Hillman, The Dissatisfied Participant, supra note 13, at 35 (potential loss of going concern value discourages liquidation). 
it is surely an empirical question whether such an extreme rule leads to less or more dissolution than alternative remedy regimes.

The second remedy scheme, resembling the traditional situation in closely held corporations, allows a participant (shareholder) to bring suits, based on fault or contractual agreement, against fiduciaries or the ongoing enterprise. Because courts rarely go so far as to dissolve corporations, one might think of there being an exclusivity rule of the opposite kind in this arena: "Litigate but do not leave it." 25

\section{B. Choice of Form}

One way to think about the comparison between the traditional partnershipchicken scheme, which anticipates only dissolution (and the threat of it), and the close-corporation scheme, which encompasses suits for fiduciary breach and other invitations to judicial monitoring but anticipates no serious threat of dissolution, is from the perspective of the choice of form. There is a large body of literature on the choice between the partnership and corporate forms, but surprisingly little attention is given to the different remedy regimes. If potential joint venturers believe that threats generate bargains, that judicial monitoring is costly, time consuming, and prone to error, and that the threat of destruction of going concern value will only rarely need to be exercised, then they might well prefer the traditional partnership form with its exclusivity of remedies rule. Other investors, however, may have greater faith in judicial monitoring or greater fear of the chicken game created by the love-it-or-leave-it approach associated with the exclusivity rule of traditional partnership law. In short, an interesting snapshot of bygone law reveals different default rules associated with the corporate and partnership forms. Although the choice between these forms is often described as based on limited liability, governance, or tax considerations, the choice may also be based on the stark contrast in available remedies regarding internal disputes.

One problem with this view is the mandatory nature of these default rules. Another problem is that the most natural default rule providing for a right to exit would seem to be one that guaranteed exit and also allowed litigation in an ongoing relationship. As suggested below, this may be where both partnership and corporate law are heading, but the important point for present purposes is

25. In contrast to the partner's right to dissociate, a shareholder cannot demand to be permitted to exit with a proportional share of the firm's value, unless an appropriate and specific buy-out, appraisal, or other right has been bargained for or legislated. There is, of course, important commentary suggesting that there be a right of ready exit from close corporations. See, e.g., J.A.C. Hetherington \& Michael P. Dooley, Illiquidity and Exploitation: A Proposed Statutory Solution to the Remaining Close Corporation Problem, 63 VA. L. REV. 1 (1977). It is interesting that Hetherington and Dooley recommend that their rule be itself love-it-or-leave-it; partnership law is mimicked with the idea that an investor can force exit or even dissolution if there is otherwise no agreement to buy the offered shares, but the shareholder who seeks to sell or part ways cannot force partial dissolution. Id. at 50-51. More generally, the trend in close corporation cases is toward granting exit rights, so that partnership and corporate law are converging. See William L. CARY \& Melvin A. EISENBERG, CaSES AND MATERIALS ON CORPORATIONS 542-44 (7th ed. unab. 1995). 
that the two different default rules associated with traditional partnership and corporate law can be seen as providing, or perhaps as having once provided, a conspicuous choice to coventurers. ${ }^{26}$

\section{Love-It-or-Leave-It and Bargaining Space}

A recurring question in the law and economics literature is whether bargains are more or less likely when there is more uncertainty and more at stake. On the one hand, parties would not want to expend resources going through trials, weathering shutdowns and labor strikes, or enduring any of a variety of other costly skirmishes if there were relatively little to be gained compared to the costs of conflict. But, on the other hand, risk aversion might lead parties to settle more readily where the risk of not settling is more substantial. The obvious analogy is to the variety found in fee-shifting rules. ${ }^{27}$ The British rule, which requires the losing litigant to pay the winner's reasonable attorney's fees, has something in common with the love-it-or-leave-it rule in that both raise the stakes for those who insist on proceeding to litigation. One novel but perhaps simplistic way to think about love-it-or-leave-it rules generally is to recognize that to the extent they raise the stakes in a dispute by allowing only claims for final accounting, the law reflects an intuition that settlements (including the simple decision not to complain) are more likely when there is more uncertainty. ${ }^{28}$ Of course, this intuition may be wrong. Settlement will also depend on the parties' relative optimism. ${ }^{29}$ And settlement may have more to do with the information that parties find worthwhile to share than with the bargaining space

26. For more on the idea of these exclusivity rules as historical default rules and on their future convergence, see infra part V.D.2.

27. John J. Donohue III, Opting for the British Rule, or If Posner and Shavell Can't Remember the Coase Theorem, Who Will?, 104 HARV. L. REV. 1093 (1991) (accepting inherited wisdom that feeshifting encourages risk-averse parties to settle but questioning claims regarding settlement differentials when risk effects are ignored).

28. One implication of this perspective is that we might expect to find different love-it-or-leave-it rules in a jurisdiction with more or less fee-shifting than ours. The simplest form of this suggestion is that our love-it-or-leave-it rules may be substitutes for fee-shifting rules.

One potential example comes from the law of estates. United States law permits no-contest provisions in wills so that a testator can force a beneficiary to love it or leave it. If a beneficiary challenges a will with a no-contest clause, then the beneficiary forfeits his benefits under the will, unless the challenge has probable cause or likelihood of success, or unless the suit is determined to be one for the construction of the will. We might expect the British rule to be different because the well-known fee-shifting in Britain might serve much of the purpose of a no-contest clause. Unfortunately, this expectation is too difficult to assess. One problem is that rules in both countries are difficult to pin down. For U.S. law, compare Porter v. Baynard, 28 So. 2d 890 (Fla.) (suit to strike provision as against rule against perpetuities not a contest of the will), cert. denied, 330 U.S. 810 (1946), with Smithsonian Inst. v. Meech, 169 U.S. 398 (1898) (giving effect to clause despite contest brought in good faith); Cocklin's Estate, 17 N.W.2d 129 (Iowa 1950) (holding suit to invalidate codicil did not trigger no-contest clause); Barry v. American Sec. \& Trust Co., 135 F.2d 470 (D.C. Cir. 1943) (clause effective absent allegation of forgery or subsequent revocation); UNIF. PROBATE CODE § 3-905 (last amended 1969), 8 U.L.A. 383 (1983). The British, in turn, appear willing to ignore no-contest clauses when there is "probable cause." An optimist might say that the British de-emphasize the love-it-or-leave-it strategy inasmuch as they already have fee-shifting, but the context-specific nature of many of these applications makes it difficult to compare the British and U.S. rules.

29. See Donohue, supra note 27. 
between them. ${ }^{30}$ However, rather than pursuing this matter, this article suggests that the choice of an exclusivity rule can be usefully situated in the larger literature on the choice between "property rules" and "liability rules." A discussion of this literature-and some additions to it-now follows.

IV

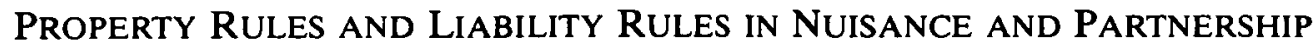

\section{A. Introduction}

Inasmuch as most readers will be familiar with the literature just referred to, it may be useful to begin with a quick explanation of how love-it-or-leave-it rules, in partnership or elsewhere, tie in to the choice between property and liability rules. A serious exclusivity rule in partnership law, by way of example, gives a partner the right to exit and, at least in some sense, the right to bring a halt to the partnership. Similarly, a property rule in nuisance law might allow a party to halt the activity of an offending neighbor. The power to stop an activity - and not simply to collect damages for the injuries it generates-is thus common to both settings. ${ }^{31}$ Correspondingly, the settlement value to a partner of the threat to withdraw capital and to inflict a suit for final accounting is much like the endowment effect enjoyed by one who obtains, or might obtain, injunctive relief against a neighbor's nuisance.

When the property-rule character of the love-it-or-leave-it practice in traditional partnership law is put this way, it obscures the fact that the most striking thing about the partnership rule is not that it equips a partner with the right to stop an activity, or force a dissolution, but rather that it denies a partner the right to bring liability claims unless dissolution is sought. It is this feature, often all, that distinguishes (traditional) partnerships from agency and other arrangements involving personal services which can always be withdrawn. At the same time, the exclusivity tradition in partnership law raises the question of whether "property rights" in other areas of law always encompass "liability rights." This article's strategy, therefore, will be to suggest not only that partnership, domestic relations, and other law can be understood by thinking of their remedies in property-liability rule terms, but also that the exclusivity traditions encountered in these areas of law reflect some light on nuisance law and other areas where the choice between property and liability rules is already celebrated-but perhaps not entirely understood.

The next few sections of the article begin with a quick review of Calabresi and Melamed's property-liability framework and then explore some extensions

30. Ian Ayres \& Eric Talley, Solomonic Bargaining: Dividing a Legal Entitlement to Facilitate Coasian Bargaining, 104 YALE L.J. 1027 (1995).

31. Thus, much as an injunction might permit B to stop A's factory, a dissolution right permits B to stop A's partnership or marriage. On the possibility that a true property right always includes a "lesser" liability right, see infra text accompanying notes 50-53. 
of this framework in order to prepare for a return to a discussion of love-it-orleave-it rules and an attempt to situate these rules and their competitors in the expanded property-liability framework. Although this is surely not the place to rethink the Calabresi-Melamed framework, the extensions reported and developed here may be independently interesting. ${ }^{32}$

\section{B. The Calabresi-Melamed Four-Rule Framework}

In the classic setting, one or more residential neighbors, collectively called B, seeks relief from a neighboring factory, A. In their famous work, Calabresi and Melamed taught us to consider four options available to a court hearing a claim by $B$ against $A .^{33}$ First, the court can decide that $A$ is indeed a private nuisance, and it can enjoin $A$. A may be able to bargain around this rule by buying B's property or simply paying B for permission to do what the court has agreed to allow B to halt, ${ }^{34}$ but the court will have established the property rights, or starting point, of this bargaining process. Second, the court can use a liability rule, requiring $A$ to pay damages to $B$. Third, the court can do the opposite of the first rule, permitting $A$ to continue as before. Fourth, the court can start with the first rule, allowing B to stop A, but it can also require B to compensate A.

On inspection, this fourth and most celebrated option is conceptually interesting but unlikely to be terribly appealing except in a very weak form. In the very circumstances in which it is tempting - perhaps because there is some fear that B has "come to the nuisance" in order to extort and could just as well have located elsewhere or perhaps because the defendant enjoys the court's sympathy for having done nothing actively antisocial-the defendant will often enjoy increased property values. Specifically, a previously unobjectionable use or activity is just the sort of enterprise courts will enjoin when there is an influx of residents. ${ }^{35}$ Thus, although $\mathrm{B}$ complains and wishes to stop A, B has also enriched A. Put differently, we can imagine that the owner of a feedlot or dogbreeding enterprise rejoices rather than frets when residential development approaches. Litigation may of course ensue; however, when this legal conflict ends, the first property owner, $\mathrm{A}$, is almost certain to enjoy increased wealth, for development tends to increase property values. Inasmuch as A's land may be more profitably developed in the future than in the present, it is possible that A's land will actually fall in value when the court enjoins the current use, but it is plain that A's property's value has not fallen if measured from some point

32. See Saul Levmore, Rethinking Remedies: Property Rules, Liability Rules, and Elastic Rules (draft manuscript, on file with author).

33. Guido Calabresi \& A. Douglas Melamed, Property Rules, Liability Rules, and Inalienability: One View of the Cathedral, 85 HARV. L. REV. 1089 (1972).

34. Id. at 1105-06.

35. A well-known example, where coming-to-the-nuisance proves to be no bar to complaints, is Ensign v. Walls, 34 N.W.2d 549 (Mich. 1948) (residents in conflict with preexisting dog-breeding operation). 
before B's arrival on the scene. It is no accident that the notable case of Spur Industries, ${ }^{36}$ which Calabresi and Melamed anticipated with their fourth rule, simply held that B must pay A's moving or relocation costs. ${ }^{37}$ Whatever one's intuition about the injury A "causes" B, it is also the case that B has caused A's land to appreciate. The disinclination to award more than relocation costs reflects either a sense that justice does not call for a double payment from B to A or a fear of moral hazard. ${ }^{38}$

\section{Novel Rules}

1. The Post-Calabresi-Melamed Literature. If one takes the CalabresiMelamed framework to suggest that a variety of mixtures of original endowments, liability rules, checks on moral hazards, and incentives can produce behaviorally similar, efficient results, then other rules can also be anticipated. The three extensions offered below illustrate the plasticity of the propertyliability framework in thinking about a wide variety of judicial and other legal moves. They also illuminate the set of plausible rules in partnership law and other legal fields where love-it-or-leave-it and exclusivity rules have blossomed.

Students of the torts literature will hardly be surprised by the idea that Calabresi-Melamed missed some rules. There is, for example, Professor Polinsky's provocative exploration of "partial property rules," with which courts might grant injunctive relief to the extent that they are confident and promise damages where they are not. ${ }^{39}$ Rather than allowing B to stop A, courts could allow $B$ to stop A from engaging in some level of operation and award damages for operation below that level. Inasmuch as this particular extension of the Calabresi-Melamed framework has no special application to partnerships or love-it-or-leave-it questions, this article will not dwell on it. One might think of it as fitting in between Calabresi-Melamed's first and second rules. ${ }^{40}$

Professors Krier and Schwab, with imagination rivaling that of Calabresi and Melamed, have suggested another extension of the four-rule framework. ${ }^{41}$ They offer as a fifth rule the idea that B stops A, but also pays to A, not A's

36. Spur Industries, Inc. v. Del E. Webb Dev. Co., 494 P.2d.700 (Ariz. 1972).

37. Id. at 708.

38. If A collects more than its relocation costs, A may decline to convert the use of its property until litigation takes place. Of course, there is still a more limited moral hazard when A collects bare relocation costs, because $A$ may defer relocating until such time as a court awards these costs.

39. A. Mitchell Polinsky, Resolving Nuisance Disputes: The Simple Economics of Injunctive and Damage Remedies, 32 STAN. L. REV. 1075 (1980).

40. This characterization ignores the question of how often there really is the kind of second rule (B collects damages from A) that Polinsky, supra note 39, for example, builds on. In many settings it is likely that if a party continued its activity, and anticipated paying damages, a court would eventually allow punitive damages, criminal law, or even property rules to control the defendant's behavior. In other circumstances, however, where judges are genuinely uncertain about the relevant costs and benefits, the attraction of the second rule may be real enough for judges to maintain it. In any event, when the second rule comes in the form of a strict liability rule (which I will leave unnumbered), there is no reason to think that the defendant cannot continue its activity as before.

41. James E. Krier \& Stewart J. Schwab, Property Rules and Liability Rules: The Cathedral in Another Light (Dec. 1994) (unpublished manuscript, on file with author). 
costs of moving or some other amount keyed to A's circumstances, but B's alleged damages. ${ }^{42}$ The idea behind this fifth rule is that when A's activity causes B $\$ X$ in harm, B ought to be willing to pay $\$ X$ in return for A's ceasing the harmful activity. Because Krier and Schwab structure the rule as an option given to $\mathrm{A},{ }^{43}$ this fifth rule might be classified as a property rule. ${ }^{44}$ In any event, the idea of working with B's enrichment from A's cessation rather than with A's costs of cessation or conversion to another activity may be attractive if there is cultural or political sympathy for A or where B's claim is difficult to verify.

Unfortunately, this fifth rule comes with its own problems. The first of these problems suggests immediately why one is unlikely to find this rule applied to partnership disputes. Although the rule may combat the moral hazard of B's coming to a nuisance and exaggerating damages, because $B$ may be required to pay that which $B$ claims to have lost while A's activity was in progress, the mirror-image risk arises that $\mathrm{A}$ will create problems for $\mathrm{B}$ in order to extract payments equal to B's damages but far in excess of A's avoidance costs. ${ }^{45}$ Second, an offer-asking problem, or endowment effect, may prevent B from paying the amount required by this fifth rule, even where $A$ would be unable to bargain for the right to continue as before if $\mathrm{B}$ had been awarded the property right (as suggested by the first Calabresi-Melamed rule) ${ }^{46}$

Note also that this fifth rule is not as strange as it first seems. It is true that we regularly encourage citizens to do $\mathrm{X}$ rather than $\mathrm{Y}$ by taxing or forbidding $\mathrm{Y}$, but it is hardly unusual to subsidize $\mathrm{X}$ instead. Both the fourth and fifth rules reward or subsidize A's switching to another activity; one simply looks for the minimum amount necessary to encourage the switch, while the other asks

42. One could imagine two versions of this rule. In one, B pays if A stops, and in the other, $\mathbf{A}$ must stop and B must pay. Krier and Schwab favor the first, id. at 30-31, perhaps because they like the idea that misestimation of B's damages need not lead to an inefficient cessation of A's activity. In contrast, the advantage of the second version is that it controls B's claim. Indeed, the second version of the rule can be seen as an example of the kind of self-assessment scheme that our legal system could probably resort to more often.

43. Of course, it could also be seen as an option offered to B to bring suit against A, where such suit gives $\mathbf{A}$ an option to stop and collect damages from $B$.

44. The fact that B's damages define the amount of the subsidy or incentive to A does not necessarily turn this into a liability rule, because we normally think of liability rules as compensatory.

45. In some sense the fifth rule is therefore nothing new but rather a clever way of describing the extortion fear that accompanies too firm a belief in private bargaining. Thus, in a Coasian world, we can ask why intentional torts need to be actionable, inasmuch as B can always pay A not to kick B, and so forth. The answer presumably relates to the problem of separating credible from "mere" extortionary threats.

46. Thus the fifth rule is not of much help in cases like Rodgers v. Elliott, 15 N.E. 768 (Mass. 1888) (no liability for extrasensitive plaintiffs alleged injuries from defendant's ringing of church bells). An extrasensitive person might not have the means with which to buy relief (quietude, for example) from a noisy neighbor, even though the noisemaker might have been unable to buy the right to make noise if the right to tranquility had been allocated to the sensitive person in the first place. 
the beneficiary to pay over what it would gain. A bargain might have materialized anywhere in between these two poles. ${ }^{47}$

2. Forward-Looking Rules. The remaining extensions of the CalabresiMelamed framework draw attention both to temporal flexibility and to the fact that such flexibility sometimes seems to be kept deliberately out of judicial bounds. Consider a sixth rule, under which a judge gives no damages for past injuries suffered by $B$, but specifies the rate at which, or simply hints that, damages will be assessed for future injuries if A's behavior continues. Free of the property-liability framework, one recognizes this strategy as a fine, and is accustomed to legislative and administrative moves of this sort. Moreover, it is easy to imagine the occasional attraction of such a rule. Liability seems more attractive where there is notice, and forward-looking liability has this feature. More interestingly, when liability is only forward looking, the defendant has a chance to cease the offensive behavior with no liability at all. The knowledge that courts are likely to use only forward-looking remedies (of the property or liability rule type) in some settings may therefore avoid the problem of chilling activity in the face of uncertainty about what courts will find to be wrongful or otherwise actionable.

This sixth rule (A pays B's future damages) reveals that the more familiar second rule (B collects damages from $A$ ) is less pliant than it first seems. A party is unlikely to give up the right to collect past damages without appropriate consideration. It is one thing to say that if a court uses the second rule, A can still bargain with $B$ so as to allow A to continue its activity while paying less than a court's liability rule decrees (and A's payment for past harm should not affect A's marginal decision about future behavior), but it is quite another for A to anticipate and then bargain preemptively regarding the likelihood of future retrospective liability. The prospect of a liability rule may thus be much more like that of a property rule than it initially seems, because, to the extent that liability rules encompass damages for past behavior, potential defendants will wish to bargain in advance before putting themselves in a position where they can be held liable for past practices. This description of the utility of fines, or the sixth rule (A pays B's future damages), raises the question of why judges do not issue exclusively forward-looking liability decisions and why CalabresiMelamed miss this option. For now, I note simply that it is not within our legal culture for judges to do this. Property rules but not liability rules-which is to say injunctions but not damages-often come in exclusively forward-looking forms. ${ }^{48}$ Courts can of course come very close to this sixth rule (A pays B's

47. And as for comparing the fourth (B stops A but pays A's net loss) and fifth (B stops A but pays B's enrichment) rules, it may be useful to note that we often fear subsidies more than taxes, because the former can be exploited in a way that comes close to moral hazard concerns. However, we do see a role for subsidies-especially if they must be financed by interest groups that bring about the policy (favoring the activity that is encouraged by the subsidy) in the first place.

48. See infra text accompanying note 53 . 
future damages) without levying fines; for example, they can find that something was a nuisance only in the very recent past, awarding minimal damages but promising larger future damages if A's behavior continues. Similarly, they can begin with the first rule (B stops $A$ ) but then sanction the violation of this injunction with damages. The first of these strategies (or low-level subterfuge) may be unsuitable where juries are in control of factfinding. ${ }^{49}$

By focusing on the ability of law to separate the past and future, the question of the relationship between Calabresi-Melamed's first and second rules becomes yet more interesting - and suggests still another missing rule. If a court chooses the first rule and issues an injunction stopping $A$ on behalf of $B$, does such a property rule necessarily promise damages for past losses suffered by B at the hands of $A$ ? There is no doubt that a court can and often will provide injunctive relief along with damages for the past, but the Calabresi-Melamed analysis implies a separation of the two remedies. Thus, the claim that a property rule can be superior to a liability rule when the latter involves damages that are difficult to assess virtually assumes that the property rule listed by Calabresi-Melamed does not itself include damages for past injuries. ${ }^{50}$ Nevertheless, let us consider their first rule to be the stronger version of a property rule, so that B stops A and also collects from A for past injuries. This version is strengthened by the idea that "property" is a bundle of rights normally thought to include the lesser right of bringing liability suits. In any event, under this version of the first rule, the second rule (B collects damages from A) becomes a subset of the first (B stops A and collects from A).

There is, then, room for another rule, which we can label the seventh rule, under which B stops A but collects no damages for A's past behavior. Note that both the sixth rule (A pays B's future damages) and the seventh rule (B stops A but collects no damages) are forward-looking in that they offer no damages for past injuries. It is easy to see how the seventh option might empower courts in public law and even in private law cases to take progressive or even radical steps. Indeed, it is possible that plaintiffs would argue for the seventh rule (B stops A but collects no damages) over the first (B stops A and collects from A), if the two were mutually exclusive, although they are not, because the first may often be too powerful to gain currency. This choice is examined in terms of plaintiffs' preferences because, as a matter of practice, it may often be the case that the first and seventh rules are not choices available to courts so much as to plaintiffs who can decide whether to ask for the seventh rule. ${ }^{51}$ In asking for the seventh rule (B stops $\mathrm{A}$ but collects no damages),

49. There are, therefore, interesting comparative law implications as to the mix of property and liability rules found in different legal systems.

50. Calabresi \& Melamed, supra note 33, at 1092 (commenting on property rule with the point that once "the original entitlement is decided upon, the state does not try to decide its value"). But see id. at 1119 (comparing entitlement protected by property rule to one protected "only" by a liability rule).

51. This is hardly the place to explore the question of when courts will give relief that no party has quite requested, or when a party must elect among the available remedies. The point in the text is simply that when the plaintiff, for example, asks for less rather than more, a court might be more willing 
plaintiffs may preclude their own later claims for damages, but they may make it easier for courts to give them what they request. By asking for the first rule (B stops A and collects from A), plaintiffs may create some awkwardness for courts, which will need to find reasons to give equitable relief but not damages if giving both seems unwise or unjust. ${ }^{52}$ In any event, this seventh rule (B stops $\mathrm{A}$ but collects no damages) rings familiar in many areas of public law where judicially imposed changes in criminal procedure and in the operation of public facilities such as prisons and schools come about in part because courts do not feel compelled to apply new law retroactively. ${ }^{53}$ And we can surely imagine private law courts giving themselves a choice between the first and seventh rules (along with others) - even if it is normally the case that plaintiffs can limit the courts' options by asking for either the second rule (B collects damages from $A$ ) or the seventh rule (B stops $A$ but collects no damages) or by merging two claims together and thus forcing courts to choose between the first rule (B stops $A$ and collects from $A$ ) and no relief, which may be to say the third rule ( $\mathrm{A}$ is unstoppable). ${ }^{54}$

\section{The Property-Liability Framework and Partnership Law}

This article has cultivated more theory than can possibly be directly relevant to understanding love-it-or-leave-it and liability rules in partnership law, and this is not the place for a full exploration of these rules and their temporal features. The immediate suggestion is that there are useful connections between partnership law, or even love-it-or-leave-it rules generally, and the propertyliability rules framework. As previously noted, there are joint ventures where participants can sue for damages but not necessarily exit, others where the right to exit and gain one's fair share is the exclusive remedy, and still others where one can have both the exit option and the right to sue for damages without

to comply.

52. If the plaintiff requests "too much" of an injunction and does not request damages, a court can tailor the injunction.

53. One method of retrospective application is to permit (or even automatically grant) claims for damages for past actions.

If Calabresi-Melamed intend for their first rule (B stops A) to exclude retrospective damages, then I should have numbered as seventh the option of a powerful property rule that included liability rights. In any event, there are three rules (first, second, and seventh) where Calabresi-Melamed count only two. Moreover, this counting itself ignores Polinsky's rule. See supra notes 39-40 and accompanying text.

54. The choice between giving courts or plaintiffs these menu-setting choices is part of what I must leave for another project. My intuition is that a clever court can virtually always give itself a choice between the first and seventh options. It can, for example, use the seventh option where the first was requested by deciding that there is a nuisance to enjoin but that it has only risen to the level of nuisance (or negligence) in the very recent past.

Note also that the third rule can itself be thought of as a love-it-or-leave-it rule where the party's option is to stop or leave the relationship with no possibility of damages for what has occurred. In situations where a party's options are limited to exit and voice, one might think of the third rule as in effect. 
exiting. ${ }^{55}$ If the right to exit, or dissolve an arrangement, is recharacterized as the right to stop the joint venture, then there is the equivalent of the following: B stops A but collects no damages, B collects damages from A, and B stops A and collects from $A$. These are the seventh, second, and first rules discussed above.

Remarkably, partnership law also adopts the fourth Calabresi-Melamed rule (B stops A but pays A's net loss). As discussed earlier, when a partnership agreement is for a specified period or project, or even where it is not but where courts regard a party's exercising the power to force dissolution as exploitative, the doctrine of wrongful dissolution can be used to extract damages from the partner who insisted on stopping the venture. ${ }^{56}$ There is, therefore, a set of cases where B can stop A but must pay A damages. The "relocation and moving costs" referred to in the lone celebrated case noted earlier ${ }^{57}$ have a direct counterpart in the damages paid by the wrongful dissolver. And partnership law, explored in the manner just suggested, reveals at long last a practical side to Calabresi-Melamed's theoretical ingenuity.

As for the extensions developed here, the fifth rule (B stops A but pays B's enrichment) would allow a court in a wrongful dissolution case to have the dissolver pay the partnership not the damages suffered by the partnership or remaining partners but rather the gain to the dissolver. In cases where the underlying problem is that partners have a fundamentally different view of how best to earn profits or what level of risk in which to engage, however, the wronged partner cannot possibly believe that his damages are less than the dissolver's gain. ${ }^{58}$ In all these cases, the advantage of the fifth rule (B stops A but pays B's enrichment) is absent; its strong point is that it serves as a check on the damages claimed by a plaintiff, but in the partnership context the

55. See supra part III.A (contrasting corporate rule with traditional partnership rule); supra note 10 ("Revised" Uniform Partnership Act rule allowing dissociation but also permitting other claims).

56. See supra note 23 and accompanying text (rightful and wrongful power to dissolve); supra note 13 (courts finding wrongfulness in order to prevent perceived exploitation).

Note that we might not expect Calabresi-Melamed's third rule ( $A$ is unstoppable) in partnership law because courts would need to force personal services in many cases. See UPA \& 31, 6 U.L.A. at 376 ("The relation of partners is one of agency. The agency is such a personal one that equity cannot enforce it even where the agreement provides that the partnership shall continue for a definite time."). But see supra note 13 for the point that foreign jurisdictions do not allow a partner to force dissolution of a partnership for a specified term. Of course, many of these jurisdictions are more generally inclined toward remedies in the specific performance family.

57. Spur Industries, Inc. v. Del E. Webb Dev. Co., 494 P.2d 700, 708 (Ariz. 1972).

58. The dissolver may be wrongful either because he breaks an agreement as to the term of the venture or because he drastically destroys synergy. Either way, the very nature of the complaint against this dissolver is that there is loss, not gain, in dissolution.

Put quite differently, the fifth rule (B stops A but pays B's enrichment) imitates the worst bargain that the plaintiff or dissolver, B, would agree to, for it aims to capture his gains from stopping $A$ or the venture. In the nuisance context, these gains are known because the plaintiff can be asked to claim damages before the court decides whether to go with the second (B collects damages from $A$ ) or fifth (B stops A but pays B's enrichment) rule. But in the partnership context, the fifth rule would present a valuation task where none existed before. 
dissolver need not normally self-assess the damages from continuing on with the venture. $^{59}$

Finally, the sixth rule (A pays B's future damages) suggests that forwardlooking damages, or judicial fines, are sometimes useful and that a party subject to this remedy will occasionally find it worthwhile to continue the offensive behavior and pay the forward-looking damages, fines, or taxes, which the court has specified or simply threatened in the past. In other settings, the defendant will prefer the option of ceasing the offense and owing nothing at all. In one weak sense, partnership law may exhibit this rule as well. If $B$ brings a suit against her partner $\mathrm{A}$, then, as discussed earlier, it is traditional or possible for a court to refuse to explore the claim unless a claim for final accounting is brought at the same time. A, however, is generally free to change his behavior or to force dissolution himself, so that if $A$ is fearful that one day in a final accounting $B$ will collect for the matter complained about (but not judicially decided), $\mathrm{A}$ is able to avoid this liability. Moreover, it is at least plausible that if in a final accounting $B$ complains for the first time about past wrongful behavior by $\mathrm{A}$, having never expressed this objection to A (by direct communication or through a rejected lawsuit), a court might discount or even ignore B's claim. It is thus possible that courts feel quite free subtly to apply the sixth rule (A pays B's future damages) in partnership law. Unfortunately, it is difficult to test this hypothesis, if only because courts could not possibly feel limited to the sixth rule. ${ }^{60}$ But without the property-liability rules framework-and the extensions suggested here-there would have been no clue to suggest looking for this explanation of partnership cases.

59. Some of these issues arise in cases where a partner has usurped a business opportunity. But in these cases valuation problems can normally be entirely avoided by the imposition of a constructive trust. Indeed, this explains the fact that constructive trust cases form a common exception to the traditional exclusivity rule in partnership law. See supra note 8 ; infra note 71 (constructive trust as an exception that does not implicate serious factfinding resources). Note also that when the offended partner objects to an alleged usurpation of opportunity, the time that passes between learning about the usurpation and objecting (or simply bringing a lawsuit) provides an opportunity for one party's expected gain to exceed the other's losses, because the plaintiff may be able to engage in "strategic delay" in order to see whether the competing business is something to be envied. See generally Saul Levmore, Strategic Delays and Fiduciary Duties, 74 VA. L. REV. 863 (1988).

60. If B turns up evil behavior by $A$, a court would surely be empowered to use the second rule, though it may defer action until a final accounting. 


\section{SELECTING REMEDIES}

\section{A. Bargaining Costs, Error Costs, and Moral Hazards}

The literature on why and when judges might, or might be encouraged to, embrace one or the other of the Calabresi-Melamed rules, or for that matter choose among remedies in general, is murkier than the framework itself. ${ }^{61}$ Conventional wisdom is that property rules are appropriate "shortcuts"-that is, decisions in the presence of, and in an attempt to economize on, transaction costs-when the likely results of hypothetical bargains are fairly clear. ${ }^{62}$ For example, rather than allowing a nuclear weapon to be constructed in A's backyard, requiring A to pay damages if something goes awry, and expecting A's neighbors to bargain for A to switch hobbies, a property rule allowing neighbors (or the state) to stop A provides a convenient shortcut. Theoretically, a liability rule ought to produce the same result. Therefore, the advantage of property rules where the hypothetical bargain is clear is either that judges and especially juries might underestimate damages or that defendants like A might occasionally be undeterred by damage awards, if only because they anticipate a judgment-proof future. There might also be some benefit in encouraging future parties to bargain rather than await official damage assessments.

Liability rules, in contrast, are regarded as superior when the hypothetical bargain is less clear, because judicial error as to negligence can be overcome by the defendant continuing as before while paying damages. ${ }^{63}$ There may also be moral and political advantages in allowing judges to balance some of the wealth effects at stake by requiring the winner in property-rights terms to pay something to the loser.

In short, liability rules provide judges with flexibility, but the very nature of these remedies requires time and effort by the factfinder. ${ }^{64}$ Property rules are said to be preferable where the parties can bargain better than judges can assess damages, but this seems to undervalue the point that parties can always bargain

61. There is also the question of when to structure rules with enrichment rather than injury in mind. See A. Mitchell Polinsky \& Steven Shavell, Should Liability Be Based on the Harm to the Victim or the Gain to the Injurer?, 10 J.L. ECON. \& ORGANIZATION 427 (1994).

62. Krier \& Schwab, supra note 41 , at 13.

63. Calabresi \& Melamed, supra note 33, at 1119. But see Krier \& Schwab, supra note 41, at 15; Polinsky, supra note 39, at 1111. See also supra note 40 (question of whether parties could really continue as before and pay damages).

64. In theory, judges could choose wildly high approximations after expending very little time and effort, and such liability rules might dominate property rules because the defendant would be left with some room to continue its activity while over-paying for nonnegligently imposed harms. But our notions of due process make such a low-cost version of a liability rule difficult to fathom. Moreover, in some settings the wrongdoer can "choose" the liability remedy by destroying the property in question-unless the law further deters such self-help. 
around liability rules as well. ${ }^{65}$ As such, the choice seems to depend on the question of whether the benefit from flexibility, in mitigating wealth effects and in allowing deadlocked parties to continue as before while paying damages, exceeds the cost of assessing damages and the danger of behavioral insensitivity. ${ }^{66}$

The preceding paragraph summarizes a bargaining-based view of the choice between property and liability rules. A somewhat different perspective discounts the differences sketched above and emphasizes instead the moral hazard problems. Property rules would seem rather generally to create graver moral hazard problems because the winning party is in a position to extract payment from the loser whenever the court errs and the value of business-asbefore to the winner exceeds the real costs of injury-as-before to the loser. It may therefore be profitable to come to a nuisance or to bring a complaint where no serious harm is really suffered. A liability rule creates a comparable moral hazard only where there is misassessment and damages are set too high. Thus, the common preference for liability rules over property rules in tort law conflicts may reflect an instinct for avoiding moral hazard problems. As already intimated, the fifth rule (B stops A but pays B's enrichment) may be unappealing to real judges for the same moral hazard-related reason that subsidies are often ridiculed in public policy debates. In short, one way to think about these rules is not as liability versus property, but rather as whether or not a moral hazard problem is present.

This article has already suggested that the superiority of liability rules on moral hazard or activity-level grounds becomes even more pronounced when liability rules can be structured as purely forward-looking. ${ }^{67}$ But, as also noted, our legal culture appears to encourage legislators and regulators-but not judges - to use forward-looking liability schemes. Courts will often find it awkward to use forward-looking liability rules without also assessing damages for past conduct and harms. In contrast, they can probably enjoin future activity without awarding past damages. ${ }^{68}$ A reasonable observer might in the end think that liability rules are superior because they raise fewer moral hazard

65. See Krier \& Schwab, supra note 41, at 24-29. Put this way, the analogy to love-it-or-leave-it issues is again helpful. Consider, for example, the well-known idea that courts ought to be more willing to dissolve close corporations if only because, when there is going concern value, the parties can be expected to salvage this value by bargaining (for an exit price) in the wake of the dissolution decree. Hetherington \& Dooley, supra note 25 , at $27-29$. In theory, the same ought to be true where courts refuse dissolution, so that there is only a liability right and no property right. The going concern value ought once again to be preserved by rational bargainers, although the exit price for the dissident will almost surely be lower than under a property rule assignment which guarantees exit or makes dissolution more likely. The argument for or against dissolution thus seems to be more about perceptions of ex post faimess than efficiency.

66. For example, a party's judgment-proof status can enfeeble liability rules.

67. See supra part IV.C.2.

68. See text accompanying notes 50-54 (discussing seventh rule). Some readers might think it the other way around, that exclusively forward-looking damages are more likely (less awkward for courts to carry out) than exclusively forward-looking injunctions (which is to say property rules with no damages for the past). 
dangers, but that courts nevertheless occasionally choose property rules in order to economize on their own decision costs. In any event, it is likely that parties themselves behave in the shadow of backward-looking liability rules very much as they might be expected to in the face of anticipated property rules.

\section{B. Valuation Tasks and Liability Rights in Partnership but Not in Marriage}

Returning to partnership disputes, consider again the idea that the ability to force dissolution and a final accounting be regarded as a property right while the ability to bring suit for wrongful behavior, fiduciary breaches, and so forth be thought of as a liability right. As previously noted, the love-it-or-leave-it tradition in partnership law reflects the kind of property right that includes the lesser right to a liability rule because courts will permit the parties to bring other complaints to their attention once a final accounting is underway. ${ }^{69}$ Indeed, under the traditional partnership rule, the very point of bringing a claim for one's "property right" of final accounting and dissolution may be to get a hearing on a liability matter that the complaining party would in fact have preferred to bring without severing the relationship.

The previous section of this article reviewed the idea that one strategy for choosing between property and liability rules (assuming for the moment that these are the only two choices) is to favor the less flexible property rules when liability is particularly difficult for courts to assess. This perspective offers a quick insight into partnership remedies once one recognizes that, in dissolution, judges will be required to undertake the very same valuation tasks that can be avoided by refusing liability rights. If the usual advantage of property rules is that judges need not assess damages, then it is critical to see that this very advantage is absent here because a final accounting requires these very valuation exercises. Put slightly differently, property rules may sometimes be preferred over liability rules in order to avoid the explicit valuation tasks associated with the latter ${ }^{70}$ but this distinction evaporates in the partnership setting because a party's property right of exit requires an evaluation of the worth of the partnership-not to mention an assessment of deferred claims among partners that could not be brought before the property-right trigger was pulled.

One cannot go so far as to say that property rules necessarily dominate liability rules in this setting. After all, the valuation task is deferred and may ultimately be avoided when a love-it-or-leave-it (or property) rule scheme is used. $^{71}$ The argument for a love-it-or-leave-it rule on these grounds must

69. See supra text accompanying notes 50-54 (comparing first and seventh rules).

70. There are implicit valuation tasks associated with most property rules, as when a judge must assess whether a factory is a nuisance or not.

71. And, indeed, one conventional explanation for the exclusivity rule in partnership law was that it economized on judicial resources. See, e.g., Schuler v. Bimbaum, 405 N.Y.S.2d 351, 352 (N.Y. App. Div. 1978) (exclusivity rule promotes judicial economy by preventing piecemeal litigation). The exception in which the court could impose a constructive trust obviously fits this explanation. 
therefore be based on the likelihood of private bargaining and its ability to avoid the costs associated with the litigation (or separation) that a liability right might generate. The traditional love-it-or-leave-it rule was hardly ridiculous, for it is surely possible that it encouraged private ordering and economized on judicial valuation tasks. Nevertheless, the move toward a liability rule can be understood as attractive because the valuation tasks associated with the liability claim were not necessarily avoided by the property rule in the first place.

The comparison with the law of domestic relations is instructive. The loveit-or-leave-it rule governing marriage ${ }^{72}$ might be regarded as economizing on valuation work, among other things, because, even when parties proceed to divorce, courts can often avoid performing the valuation tasks that would be necessary if married persons had liability rights. It is, after all, often the case that decisions about divorce, child custody, support payments, and so forth can be made without assessing the harm imposed earlier by implicit or explicit breaches of the marriage arrangement. ${ }^{73}$ For this reason alone, it is not surprising that the law of partnership remedies has moved further and more quickly toward a liability rule than has the law of marriage and divorce. The contrary view is that many divorces do involve courts in difficult decisions, so that the preference for a love-it-or-leave-it rule requires one to consider cultural factors or to face the fundamental question of whether love-it-or-leave-it rules can be expected to lead to more rather than less compromise. ${ }^{74}$ Inasmuch as this article next turns to a different argument about love-it-or-leave-it rules for marriage, it is useful to assume that valuation tasks are indeed avoided by a love-it-or-leave-it rule in the law of domestic relations.

The focus on valuation tasks suggests less early intervention in marriages. At the same time, the role of moral hazard dangers in choosing among remedies suggests that in both marriage and business partnership settings, if there is to be judicial intervention, there might be a greater range of available remedies than in much of tort or other law. The reason is that parties would seem less likely to enter, or to be able to enter, marriage or partnership arrangements simply to profit from exit. For example, a court that hesitated to invoke the fifth rule in a nuisance case, for fear that the prospect of payment to A of B's alleged damages might cause $A$ to engage in an activity that is likely to be injurious to $\mathrm{B}$, might be more likely to experiment with a partnership (or even a marriage) case where such very ex ante moral hazard seems unlikely. ${ }^{75}$

72. See supra notes $14-17$ and accompanying text.

73. See ClARK, supra note $15, \$ 1.1$.

74. For the sake of argument, this analysis assumes that the law regards more compromise as a good thing.

75. Once there is conflict in a partnership or marriage, the moral hazard problem returns. Partners and spouses are surely capable of engaging in offensive behavior and thus imposing costs on their partners, in order to gain bargaining advantage, even where there is no intrinsic gain to the actor. But the fact that the relationship itself is relatively unlikely to be entered into in order to gain this sort of advantage suggests that there may be more room for some moral hazard-prone remedies here than in standard tort cases. 
A comparison of nuisance and partnership claims emphasizes the idea that one way to think about the evolution of partnership law is to focus on the valuation tasks peculiar to dissolution conflicts in that area of law. When $B$ seeks to shut down $A$, the injunction or property rule sought by $B$ requires no explicit valuations by the supervising judge; a rough calculation might be needed in order to decide whether this property rule is the appropriate shortcut, but no precise measurement is required. ${ }^{76}$ In contrast, when a partner moves to "shut down" a partnership, the final accounting that must be undertaken includes the very same valuation tasks as the liability suit that was shunned earlier because of the traditional love-it-or-leave-it rule.

\section{Property Rules and Not Liability Rules for Domestic Relations}

This article has suggested in passing that a love-it-or-leave-it rule for parties to a marriage contract may be superior, at least from a court's perspective, to a liability rule because the former may first postpone and then entirely avoid difficult valuation tasks. The property-liability framework points to a much stronger explanation for love-it-or-leave-it rules in marriage law.

It is easy to regard the love-it-or-leave-it rule for marriage as anachronistic. There is some irony to the claim that parties to a marriage should not litigate but should work out their problems. First, the same might be said of most other parties in conflict; if courts think that peaceful settlement is promoted by a loveit-or-leave-it rule in marriage, then it is not entirely obvious why courts do not extend that intuition to parties to other contracts. ${ }^{77}$ Second, and more important, it is precisely in the area of domestic relations, where the love-it-orleave-it rule is most robust, that a substantial industry of counseling and mediation has arisen. Private parties can be said to react to the mandatory love-it-or-leave-it rule by "litigating" in the shadow of the courthouse and turning to pastors, psychologists, and other counselors. The demand for these nonjudicial services might be regarded as a clamor for a liability remedy where none is offered by law.

Put differently, when there is conflict in marriage and dissolution is a risk, the parties' friends normally appear to think that third-party intervention promotes, rather than threatens, compromise and long-term peaceful, pleasurable coexistence. It is no accident that mediation has blossomed most in the very context in which the love-it-or-leave-it rule stands most firm in the courtroom. Why then do judges not supply law where it is apparently sought?

The question returns us to the nature of property and liability rules in different settings. It is useful to think of the remedies available to courts in business and then in marriage arrangements. Monetary relief is of course common in shareholder-corporate disputes, and it is easy to use in partnership cases where the traditional love-it-or-leave-it rule has fallen. Specific

76. Calabresi \& Melamed, supra note 33 , at 1120.

77. Parties might agree that any suit for breach releases the other party from further performance. 
performance is less common if only because it will often require postjudgment supervision. Such supervision is especially difficult and distasteful where personal services would be required from one who does not wish to perform. Injunctive relief is, of course, a kind of specific performance, and some structural injunctions do involve a great deal of monitoring (for example, prisons and school systems that do not wish to perform as required by courts). These exceptional examples make clear why courts would not wish to supervise decrees regarding married persons. Yet in most marriages, assets are commingled. It is thus hard to imagine most courts agreeing to use liability rules without a divorce decree because the judgment would have little effect if the spouses did not have separate financial lives. The alternative of specific performance would require enormous judicial involvement. Although courts do need to undertake some involvement after divorce, as when parties do not live up to their judicially imposed responsibilities regarding the payment of child support or facilitating visitation rights, the love-it-or-leave-it rule is unsurprising when one realizes the enormous tasks courts would be required to undertake were there in-marriage remedies. ${ }^{78}$ Finally, courts are simply not in the business of counseling or issuing advisory opinions to private parties.

This analysis suggests that the valuation idea does explain a great deal of the love-it-or-leave-it pattern. Even if marriage is an exception rather than another example of this theme, the use of the love-it-or-leave-it rule in marriage is best explained by the observation that a liability rule is essentially unworkable in a world where most spouses commingle their financial resources.

\section{Love-It-or-Leave-It Revisited}

1. Intuitions about Love-It-or-Leave-It Rules in Disparate Settings. What, then, explains the exclusivity rule as embodied in the first and seventh property rules in traditional partnership law? One possibility is that private bargaining is more likely if liability suits are unavailable. But, as already noted, if the parties can bargain, it should often make little difference whether they are bargaining around a property rule or a liability rule. ${ }^{79}$ It is plausible, however,

78. Note that, consistent with the analysis in the text, there is room for in-marriage remedies of the property-rule kind. Where there is a fear of violence, for example, one spouse may get a restraining order against another. More generally, when courts chip away at the love-it-or-leave-it rule, we should expect them to do so where there are modest valuation tasks and property-rule like remedies. Thus, it would not be shocking if a court came to the assistance of a spouse who wished to stop another from undertaking an imprudent investment. Still, such interventions are not to be expected outside of community property jurisdictions. Compare Kirchberg v. Feenstra, 450 U.S. 455 (1981) (holding unconstitutional Louisiana statute that allowed husbands, but not wives, to execute mortgages on jointly owned property without spousal consent), with McGuire v. McGuire, 59 N.W.2d 336 (Neb. 1953) (insisting that "public policy" requires rejection of wife's complaint about insufficient financial support).

One should recognize that when these rules were developed, spouses were regarded by the law as having separate financial assets and lives. Put differently, 50 years ago courts could have required one spouse to pay damages to the other, but they did not. The story in the text is thus incomplete, but might be enriched by adding the reality of limited liquid assets.

79. See supra part V.A. 
that with more at stake under a love-it-or-leave-it rule, parties may shy away from going to court with their conflicts. ${ }^{80}$

Imagine, as a first example, a labor law rule that barred litigation either in court or through the National Labor Relations Board unless the union was on strike or locked out. Under such a rule, the two sides to a collective bargaining agreement would have a "property right" to stop work but no stand-alone liability rule as a remedy. My intuition is that most observers would think that such a love-it-or-leave-it rule would generate more strikes and social costs than the present regime, which is more permissive of litigation including a kind of forced arbitration. The love-it-or-leave-it rule might, of course, also stimulate additional compromises (because not all disputes need trigger strikes), but the point is that there might be greater rather than smaller social and private costs under such an extreme rule.

Consider, by way of comparison, the now-familiar love-it-or-leave-it rule regarding conflicts between spouses. The parties are unable to bargain around this rule; a prenuptial contract regulating responsibilities within a marriage and in the event of divorce may carry weight in the event of a divorce, but it is most unlikely to open up the courthouse doors during a marriage. Courts treat marriage as a rather extreme love-it-or-leave-it arrangement. Here, most observers may sense that the love-it-or-leave-it rule does not increase the social costs and likelihood of divorce. There is obviously much to be said about strategic behavior and cultural norms in both the marriage and collective bargaining contexts. The narrow point is that these contrasting intuitions reflect the idea that it is by no means obvious whether love-it-or-leave-it rules, which is to say property rules, or "cliffs," ${ }^{\text {"1 }}$ promote compromises or hostile separations.

To use one more example, consider the role of mutually assured destruction in game theory about warfare. ${ }^{82}$ It is plausible that there is less war where there is mutually assured destruction, much as it is possible that there is less litigation (and dissolution) with love-it-or-leave-it rules. But the more telling comparison is whether a nation or a pair of nations would be better off armed with nuclear weapons and capable of mutually assured destruction-while possessing no conventional weapons at all. Is it plausible that superpowers would be better off giving up their conventional weapons in order to have only the threat of nuclear weapons? My intuition is that most of us think that

80. This is the argument set aside in part III.C, supra.

81. The idea is that when rules present actors with the prospect of serious liability if they step over a thin, uncertain line, these actors might be overdeterred and stand back from the line or "cliff." See SAUL LEVMORE, FOUNDATIONS OF TORT LAW 99 (1994) (suggesting that the kink or cliff or overdeterrence effect generally assumes that full rather than incrementally caused damages will be assigned to the negligent tortfeasor); John Calfee \& Richard Craswell, Some Effects of Uncertainty on Compliance with Legal Standards, 70 VA. L. REV. 965 (1984). Love-it-or-leave-it rules would seem to have this feature as well.

82. Of lasting value is THOMAS C. SCHElling, THE STRATEgY OF CONFLICT 119-61, 230-54 (1960). 
conventional weapons, and their liability rule counterparts, reduce the opportunity for exploitation and even the likelihood of mutual destruction. ${ }^{83}$

Nevertheless, it is plausible that parties would benefit from a choice between a property rule and a liability rule, or between mutually assured destruction alone and conventional weapons along with mutually assured destruction. Different intuitions about games of chicken or different reactions to different settings could easily lead to a preference for one scheme or the other.

2. Explaining the Traditional Rule in Partnership. The exclusivity rule in partnership $^{84}$ might also be explained by returning to the earlier discussion about the choice of business form. ${ }^{85}$ Once upon a time, coventurers could choose between a love-it-or-leave-it and a liability rule by selecting either the partnership or corporate form. But in a world in which this choice is dominated by tax and governance considerations, there is no room for an exclusivity rule of the kind once found. It is therefore not surprising that the corporate and partnership rules have drifted closer to one another.

At the same time, the remedies have not quite converged. The evolved partnership law norm approximates the first rule ${ }^{86}$ : a right to dissolution along with a right to sue for damages in an ongoing relationship. The evolved corporate norm is closer to the second rule ( $\mathrm{B}$ collects damages from $\mathbf{A}$ ), with a hint, and not a guarantee, of an exit right, except where an appraisal remedy or other developments creep in. It would not be surprising if the convergence trend continued. Thus, one might expect courts more often to imply agreements for partnerships of specified terms in order to withdraw the claim-free, or untaxed, right to exit. ${ }^{87}$ Alternatively, corporate law might increasingly grant requests for dissolution (or appraisal), in which case that body of law will become more like contemporary partnership law. ${ }^{88}$ If there is convergence, and a shared default rule materializes, there will be some room for debate as to whether the shared rule is efficient or instead supplants what had been useful, alternative default rules. ${ }^{89}$ In any event, one aim of this article is to draw attention to the idea that the law of remedies in partnership and corporate law

83. To the extent that it is plausible that nuclear deterrents alone would make sense if there were only superpowers, and no smaller enemies to fear, an interesting observation is that we are most inclined toward the love-it-or-leave-it-like extreme where peers are involved. Partnerships, marriages, and superpowers can be said, at least ideally or in theory, to be bargaining as equals, unlike principalsagents, corporations-shareholders, and many other areas where love-it-or-leave-it can be said to have been rejected (such as states-citizens). Because there are important counterexamples, where "peers" have ongoing litigation, this article does not pursue this theme. These counterexamples include employers-unions and, more generally, parties to most contracts.

84. See supra notes 5,7 and accompanying text.

85. See supra part III.B.

86. The labels refer again to the first through seventh rules, sketched supra in parts III.B, IV.C.

87. See supra note 13 .

88. See supra note 25 .

89. See generally Jody S. Kraus, Legal Design and the Evolution of Commercial Norms (unpublished manuscript, on file with author). 
once offered alternative and very different default rules but is narrowing over time.

Finally, it is noteworthy that the evolution of partnership law has not only been from the mold of the seventh rule (B stops $A$ but collects no damages ${ }^{90}$ ) to that of the first (B stops $A$ and collects from A), but also may have shifted toward nonmandatory default rules. The traditional exclusivity rule was substantially mandatory. ${ }^{91}$ The question is whether the modern trend toward allowing actions while the partnership continues without an accounting ${ }^{92}$ anticipates letting partners opt out of this permissive rule into a love-it-or-leaveit scheme. ${ }^{93}$ If so, which is to say that agreements not to bring actions will be enforceable or will at least provoke claims all their own, then the CalabresiMelamed framework is all the more appropriate. That framework, after all, anticipates private bargaining around the rules, except for unusual cases of inalienability. ${ }^{94}$ Put in more negative terms, one drawback to thinking about the traditional partnership remedy and other love-it-or-leave-it rules in propertyliability terms is that the property-liability framework too easily obscures the mandatory nature of some of these remedy rules.

\section{E. The Survival of Love-It-or-Leave-It in Domestic Relations Law}

The love-it-or-leave-it rule in domestic relations has come to look rather lonely. This article has suggested that its survival can be explained more by the disinclination of courts to deal with the enforcement of liability rules in the family setting than by the advantages of love-it-or-leave-it rules. ${ }^{95}$ It is possible, of course, that the love-it-or-leave-it rule in marriage will yield, as it did in business partnerships, to other rules. But the trend in the law of domestic relations can be described as heading toward yet stronger love-it-or-leave-it rules, in that courts seem less interested than before in assigning "fault" during marriage. ${ }^{96}$ At the same time, the level of judicial supervision required postdivorce regarding child custody and support payments may soon persuade courts that their jobs might in fact be easier if there were more intervention during marriages.

90. That is, unless there were wrongs that can now be assessed at the time of final accounting.

91. See supra text accompanying note 22 .

92. See supra note 23 .

93. Although we are accustomed to courts supporting precommitments to go to arbitration rather than formal litigation, courts will surely be troubled by some agreements to forgo litigation. On the other hand, courts might be inclined to allow private agreements for love-it-or-leave-it rules where the parties are seen as bargaining equals.

94. Calabresi \& Melamed, supra note 33, at 1123-24, note the possibility of giving a polluter an inalienable right to pollute in some specified amount. This can be seen as a love-it-or-leave-it rule.

95. Approximately one-third of the states have adopted "no-fault" statutes regarding the granting of divorce. WALTER WADLINGTON, CASES AND OTHER MATERIALS ON DOMESTIC RELATIONS 1033 (2d ed. 1990).

96. See supra note 15. 


\section{VI \\ CONCLUSION}

Contract law itself has evolved away from a love-it-or-leave-it rule and toward ongoing liability rules. There was a time when to bring a claim against one's supplier, for example, was to terminate the supply contract. ${ }^{97}$ Over time it appears that most parties, and therefore judges, came to prefer an expansion of remedies and, in particular, the possibility of legal intervention in a continuing contractual relationship. A sensible explanation of this and other evolutionary examples is probably that our culture, both legal and general, prefers more rather than fewer remedies and is generally disinclined to adopt a strategy of encouraging compromise and peace by denying the opportunity for modest skirmishes. It is, of course, also conceivable that this evolution is efficient. There seems to be no evidence that parties or lawmakers systematically learned that love-it-or-leave-it rules generated greater social costs (or even private $\operatorname{costs}^{98}$ ) than alternative remedy schemes, but it is possible that the law improves in mysterious ways.

If the story of these love-it-or-leave-it rules and their demise (outside of domestic relations law) reflects evolution in the direction of additional remedies, it becomes yet more important to learn to match specific remedies with particular circumstances. This article has suggested that we pay more attention to the remedies that we still struggle to imagine. Love-it-or-leave-it rules, forward-looking damage rules, and subsidies as substitutes for taxes have something in common, for they seem less unusual when closely examined and, once investigated, they look like plausible candidates for new roles in the future.

97. The rule was that a partial claim often precluded a later claim, because only one action was permitted. See E. Allan FARNSWORTH, CONTRACTS 635 (2d ed. 1990).

98. It is possible that additional remedies transform the private costs of bargaining into externalized costs for the court system. However, this effect is likely to be limited. Litigation may involve large costs that the parties do not bear, but litigation itself appears to generate very substantial private costs, if only because private bargaining is less constrained by formal rules. 
